\title{
SCOTTISH PRIZE DECISIONS OF THE SEVEN- TEENTH AND EIGHTEENTH CENTURIES
}

\author{
THOMAS BATY
}

Inner Temple, London

The neat and handy Reports of Christopher Robinson have made the decisions of the English Prize Court a ready storehouse of the laws of maritime war, just as the compilation of Pistoye and Duverdy made those of the French prize tribunals. The decisions of the Scottish prize courts, on the contrary, are sunk in the volumes of miscellaneous repertories of jurisprudence-Morison's Decisions, Stair's Compilations, etc. So far as the writer knows, they are never once referred to by editors on the law of nations, and only occasionally emerge to the light of day in treatises on the law of Scotland.

Yet they are interesting and important. Moreover, they throw light on a dark period-that preceding the dawn of Stowell and Story. For the corresponding period in England we have nothing beyond the fragmentary and meager notes put together in the volumes known as Hay and Marriott and Burrell and such correspondence as is preserved, for instance, in the Life of Sir Leoline Jenkins. Totally neglected as these Scots cases are, it would seem well worth while to have them reprinted and made generally available, for nobody is likely to break a set of Morison, or to purchase the half-hundred volumes for the sake of two.

Volume XXVIII of William Maxwell Morison's Decisions of the Court of Session . . . in the form of a Dictionary (Edinburgh, I805) contains the title Prize, at page II,857. The industry of my friend, Dr. G. C. F. Schirrmeister, Marshal of the Inner Temple, enables me to present succinctly the cases there set out.

\section{CONCLUSIONS}

On a review of the whole cases we see the following appearing mostly as early as the seventeenth century:

I. The mode of trial on the ship's papers without a word of captor's evidence, established in uniform and settled working, as declared in the Lee-Murray Memorandum of 1753 , as reported to Mr. Jay by Scott in I793, and as subsisting up to I914.

2. The corollary that throwing of papers overboard is already "an unquestionable ground of prize."

3. The recognition of domicile as the criterion of national character for prize purposes, not only for the treatment of a neutral as an enemy, but also for the treatment of an enemy as a friend.

[453] 
4. The absolute coincidence, for this purpose, of trade-domicile with personal, family domicile.

5. That true domicile is unique and single.

6. The doctrine that false documents, or no documents, make prize, unless the claimant is indulged with further proof (in which case it may be made a condition that captors shall have the same indulgence).

7. The practice of restoring prizes taken in contempt of territorial sovereignty. (Eighteenth century.)

8. The three-mile limit of territorial waters. (Eighteenth century.)

9. The fact that declaration of war is not needed to constitute war.

ro. The voluntary exemption of ships in port from capture at the outbreak of a war. (Eighteenth century.)

II. The admission of enemy persons to claim in prize. (Eighteenth century.)

I2. The independence of the prize jurisdiction from royal dictation.

The first case dates from ${ }^{5} 55^{8 .}{ }^{1}$ It establishes the principle that a lawful capture gives an unimpeachable title. Lindsay had bought a ship from a French man-of-war, but on bringing her into Leith, he was met by the claim of a former Dutch owner, who alleged that she had been taken from him by pirates. But it was decreed that, whatever her previous history, she was a just prize to the Frenchman, who took her from a Hollander "who was bringing victuals to the town of Berwick, in time of war, to furnish our old enemies of England." In other words, she was acting as an enemy's transport. It will be seen that the court examined the grounds of the capture: also that no French prize decree is alleged.

Case 2 is of $1566,{ }^{2}$ and merely establishes that capture by pirates does not of itself divest the owner's title, but it seems to recognize the recaptor's right to salvage, as they were required to bring in an account of their expenses. They had lost their own ship to the pirates and made a gallant recapture of the claimant's.

Case 3 is more important: ${ }^{3}$ no less than a determination of what constitutes a vessel neutral-a point still warmly controverted. It is of date a hundred years later (I666), and turns on the still unsettled and thorny topic of divided sovereignty. We are familiar with "leases" of territory in these days: in those, pledge was the more important (and in point of fact, the Orkney Islands and Kirkwall

${ }^{1} A$ Dutchman v. Lindsay (1558) 2 Fol. Dec. I27, Maitland MS. 127. Note, that this is not a prize cause, but a civil law issue turning on a question of prize. It is added that the carriage of victuals in wartime "prehebatur inter reges Gallorum, and the Hollanders, and the Flemings, and English. . . ."

${ }^{2}$ A Frenchman v. Scotsman (1566). Fol. Dec. ut sup. I77, Maitland, ut sup. 166.

'Paul Henrison v. Lord Ludquharn (Dec. 22, 1666) I Stair, 418, 425. 
itself were originally Danish territory in pledge to Scotland). Henrison was "an indweller in the island of Helgilland, being at the mouth of the Elbe." Heligoland was Danish, and Scotland was at war with Denmark. But the island had been pledged to the Duke of Holstein, who was a prince of the empire and in amity with His Scottish Majesty. Therefore, when Henrison was taken by a privateer and carried into Peterhead, the Admiral released his vessel, although the Admiral-Depute there (the Laird of Ludquharn) had condemned it. The case exhibits the hierarchy of courts, somewhat resembling the French; the local "Admiral-Depute"; the central "Admiral"; and the appellate Court of Session. It also shows the Admiral and the Court of Session as taking the common-sense view that in all these cases of complicated sovereignty, the actual exercise of power is the deciding element. Henrison was a subject of a friendly duke, and it was of no-concern how the latter held the island or "how he got the right thereof." The Admiral-Depute (who doubtless had some interest in the forfeiture) was hard to convince, and raised the question again on January 4, I667. But

"simple acknowledgments of a superior, or investiture from him, do not make subjects, or comprehend them within the wars and quarrels of their superiors,-yea, though there were a tribute or jurisdiction due to that superior, yet if the [inferior] prince do enjoy the privileges of making war and peace, he is not a simple subject."

He is comparable to the princes of Imperial Germany, who may pay tribute and submit to appeals to the Imperial Court, but

"because they can make war and peace, they are not necessarily involved in the Emperor's quarrels. So the Duke of Holstein, being a sovereign prince, and possessing this island, so as to make use of the subjects thereof in peace and war, is not comprehended in the King of Denmark's quarrel. ...."

Ludquharn sticking to his point, that the islanders were contributing the ship to Henrison on bail till the point should be determined, caution for damages being also exacted from the persistent Ludquharn. The cargo (the property of neutral Hamburg merchants) was directed to be sold, and not made unprofitable: probably it was perishable.

Case $4^{5}$ turns on the effect of the Swedish treaties of I66I, I664 and $1665 .^{\circ}$ Great Britain has always been anxious to limit the operation of these instruments, ${ }^{7}$ which make national certificates of cargo and destination of ship and goods conclusive and are still subsisting.

- Cf. The Ionian Ships, Spinks.

${ }^{5}$ The Riga Castle v. Capt. Seatonn (July, I667) I Stair, 48I, 483, 484, 534.

- $C f$. Wheaton, Elements, $\{482$.

'See The Maria (1799, H. Ct. Adm.) I C. Rob. 287 [340]. 
One way was to deny that the principal treaty was as wide as it appeared on the face of it. Another was to challenge the passes as forged and fraudulent if inaccurate in any particular, and thus to let in an inquiry which it was the object (and the express stipulation) of the treaty to exclude. Another was to rely on a royal proclamation confiscating ships with enemy crews, and to represent this as overriding the treaty, which was directed to different points. Another was to ignore the explanatory treaties of $1664-1665$. In the case before us, the employment of an enemy (Dutch) crew was mainly relied on: "but the pass was also challenged as incomplete, and an attempt was made to narrow the operation of the treaty." The claimants, however, produced a letter from King Charles to the effect that the ship was Swedish, and commanding the delivery up of ship and goods to themselves. This was enough for the Court of Session which, in view of treaty, weak evidence, and royal letter, annulled the decrees. But on July $3^{d}$ they reconsidered the matter. The captors had not been inactive, and now argued that an act of the Crown, done without hearing the parties, obtained upon importunity and groundless representation, must be disregarded. Acts of the Crown cannot prejudge private rights. Also, Charles had even sent another letter, warranting the court to proceed. (We may suspect some intrigues at Whitehall, and perhaps a little judicious ready cash for the privy purse.) They then proceed to argue in favour of cutting down the Swedish treaty, to which the claimants replied that a solemn treaty was not to be retrenched or limited but by the exceptions contained within itself; that the pass excludes all inquiry, and that the king's earlier letter is conclusive. The king, again invoked, wrote in favour of a restrictive interpretation of the treaty. As it had, however, been decided that the evidence of enemy ownership was not difficult to condemn, in any event, the case was finally determined February 25 , x668, on the point that the ship and goods were prize on account of having a Dutch crew. And the court now agreed that, since the king's declaration of war contained a clause ordering prize to be made of ships navigated by Hollanders and the treaty contained nothing express against this, the Admiral's decree of confiscation must stand. ${ }^{8}$

Case 5 discloses an executive interference with the prize before condemnation. Colonel Seatonn, governor of the fort at Brassie ${ }^{0}$ Sound, meddled, brevi manu, with a ship and loading seized by the Laird of Balwhilly (an uncommissioned ${ }^{10}$ captor). Seatonn was sued before

\footnotetext{
${ }^{8}$ It was alleged that the confessions of Dutch nationality were obtained by threats; and on this ground the court may never actually have proceeded to condemnation.

Bressay (?)

${ }^{10}$ As to the rights of uncommissioned captors, see Rothery, Prize Droits of Crozen and Admiralty in War (London, 1915) passim, and article by the present writer on Prize Droits, 32 LAw QUAR. Rev. (Jan. 1916) 38.
} 
the Admiral, but successfully contended that as private captors have no rights, and their captures vest in the state, the Crown was directly concerned, and the cause should be "advocated" before the Lords of Session. ${ }^{11}$

Case $6^{12}$ raises a point of evidence. Is the master's admission on the preparatory examination fatal, or has the claimant liberty to contradict it? Not as of right, said the Lords of Session, in the absence of force or fraud practised on the witness.

In Case $7,{ }^{13}$ we find the Swedish Treaty of $166 \mathrm{I}$ again discussed. It contains a long and careful enumeration of contraband. Is this exclusive? The vessel had taken tar and stockfish from Norway to France: the latter "being commeatus and contraband goods" within the treaty. She was taken on the return voyage, with Rochelle salt, the proceeds of the outward trade. The claimant argued that the ship was duly provided with the treaty pass, and should not be further vexed. Also, he urged that the quantity of tar was trivial (perhaps a single barrel), and that provisions can only be contraband when carried into a besieged place, or "to those that could not subsist without them."14 In reply, it was attempted to narrow down the scope of the treaty so as to make it apply only to home produce-and the Lords of Session having it from the king that the treaty did not cover such a case as the present, again recurred to the royal wisdom, to know whether the proceeds could be seized on the return voyage. Such a seizure was stated always to have been the custom of Scotland, a case of 1627 being cited in support. ${ }^{15}$ After deposit of the contraband, it was asserted, the delinquency was far more certain than before when it existed in intention only: it was only with a view to avoid multiplicity of suits that the liability was limited to the return voyage. Contra, it was said that the king's proclamation of war was limited to the seizure of contraband, and not its proceeds, and that a roving commission to seize ships where the cause of offense was not "sensible to the eye" would be destructive of all neutral freedom. Moreover, a certificate was produced from Sir Leoline Jenkins, the English Admiralty Judge, who declared, after consultation with the advocategeneral and search of the records, that he knew of no such practice. On February 25, r668, the lords decided to inform themselves, by commissions, of the correct procedure; the king having curtly told them to "decide according to the law of Scotland." But on July 9 the lords

\footnotetext{
${ }^{11}$ Seatom v. Balwhilly, I Stair, 487.

${ }^{12}$ Randolph Davidson v. Richardson (Dec. 13, 1667) Dirleton, No. 49, p. I20.

${ }^{13}$ Parkman v. Capt. Allen (Jan. 16, 1668) I Stair, 502, 529, 550, Dirleton, No. 132, p. 55, Dirleton, No. 153, p. 6r.

${ }^{14}$ Grotius, De jure belli, bk. 2, cap. de his quae in bello licent.

${ }^{15}$ This, however, was explained by the other side as having turned on another point-the present carriage of enemy goods by the ship libelled.
} 
cut the whole knot by falling back on their own decision in the Riga Castle, ${ }^{16}$ and condemning on the ground that thirteen (out of eight) of the crew were Dutchmen-though they had previously exonerated the claimant on this point, on the ground of necessity and distress!

Case 8 is one of competition between two privateer captors, in which the principle of sharing in the prize, although one vessel may not have been participating actively, is clearly recognized as well established. ${ }^{17}$

Case 9 deals with the hard position of a captor who obtains a condemnation which is subsequently annulled. On this instance, he lad disposed of the cargo at rubbish prices, had paid the king his fifteenth and the Admiral his tenth share. As the ship's pass was informal, the captor was excùsed from damages but was found liable for negligence in dealing with the perishable cargo, which should have been auctioned. ${ }^{18}$ And he had to restore the tenth and fifteenth.

In Case Io, ${ }^{19}$ similar considerations arose: the case is important for the captor's observation that it is not the proclamation of war that makes the war, for the king's declaration is only to give an account to the world upon what account the king had made war with the Danes. A captor having taken a Hamburg ship proceeding with contraband to Denmark, before the declaration of war, was forced to abandon it at sea, whereby it was wrecked. The lords found that the Hamburgers were entitled to carry on their trade with Denmark, and to carry to them contraband goods, but on the other hand, the captain was in no fault in executing the king's commission and was liable only to restore what profit he had made of his capture-which was nil. ${ }^{20}$ This is evidently mistaken law: a court ought always to compel restitution of property captured contrary to the rules of international law, which certainly require that a neutral cannot usually be a contrabandist without knowing of a war in progress.

Case $I I^{21}$ is a replica of the Riga Castle: several of the crew were Dutch.

Case $12^{22}$ affords an early instance of shipbuilding material being regarded as contraband. It was argued that the loading

"did not consist of such clapboard as could be made use of for the building of ships, it being prepared for making of steps to wine puncheons and for cooper work, not being but about three foot of length."

${ }^{10}$ Supra, case 4

${ }^{17}$ Capt. Coningsby v. Capt. Mastertozen (1668) I Stair, 520.

${ }^{18}$ Capt. Mertumer v. Strangers of Ostend (Feb. 26, I668) I Stair, 532.

"Merchants of Hamburg v. Capt. Dishington (Feb. 25, 1668) I Stair, 533.

${ }^{20} \mathrm{Cf}$. The Oldhamia, Sakuyé Takahishi, International Law Applied to the Russo-Japanese War, with the Decisions of the Japanese Prize Courts (London, I908) 326.

${ }^{21}$ Peterson v. Capt. Anderson (June 30, I668) I Stair, 544.

Gilbertson v. Binny (Jan. 8, 1669) Gosford MS. No. 80, p. 28, No. 157, p. 59; The King of Poland, I Stair, 626. 
And it also bears on the question of national character. Three sailors were originally Hollanders,

"yet for several years they had remained in Flanders and Bruges, and were burgers, and were taken on to be sailors in Flanders, by the merchants in Dantzic, who were not bound to inquire where they were born." The clapboard was held contraband-"a great part of the most able part of the Lords being," Stair says, "of the contrary judgment."

In case $\mathrm{I} 3$, which appears to have turned partly on the national character of the owner of goods laden on board a neutral Spanish ship, we find the individual acknowledging that he was born in Holland, but declaring that for two or three years he had been living in Ghent and Bruges under the King of Spain.

He was allowed to prove his domicile, but only succeeded in proving that in March, I667, he hired a house in Brussels and began to set up there, and that "some time before" he had lived with his mother in Ghent, without showing how long, or that it was his "constant" domicile. It was said to be a common device for Hollanders to hire houses in the Spanish Netherlands (modern Belgium) and to pretend to be subjects there:

"but they, being Hollanders at the beginning of the war, concurring and contributing to the war, even if they had truly removed tempore belli, they contrived to be the King's enemies; much less can their [merely] taking houses elsewhere sufficiently prove that they totally, deserted the Hollanders and concurred not with them in the war. ..."

This case $\mathrm{e}^{23}$ is, accordingly, important, as throwing light on the true conception of domicile as the criterion of enemy or neutral character. Apparently, it is only when it amounts to a "desertion" of the enemy, a complete incorporation with the neutral country, that it can confer a neutral character-i.e.e, it must amount to what would now be called naturalization in the neutral country. Certainly a house of trade in the neutral territory, however self-supporting, would not do. The claimants, indeed, argued that "any Hollander deserting Holland at the time of the war ceases to be an enemy,"-and they put this on a most important ground-viz., that

"the King invited such as would desert his enemies to come and live in England, so that it is both his Majesty's interest and intention in any way to weaken his enemies by causing their subjects to desert them."

Can it be that we have here the true explanation of the idea that a neutral personal domicile may confer a neutral character, or that a

\footnotetext{
"s Evart Loyson v. Laird of Ludquharn and Capt. Wilson (June 15, 1669). In this case, Ludquharn, varying his activities, appears as privateer-owner. We have already seen him as Admiral-Depute.
} 
British domicile may confer the British character, on the property of an enemy subject-viz., that it is traceable to such a special royal invitation to "desert" the enemy? It is quite clear that the modern idea that a commorant enemy resident and trading in the kingdom has rights of suit, is derived from a misunderstanding of Wells v. Williams, which was decided under a similar proclamation promising protection to enemy subjects already settled in the realm. Case I7 (post), however, treats the neutral or British character derived from domicile as existing independently of royal invitations to desert. The case before us also treats confiscation for carriage of contraband as an undisputed rule (though varied by the Spanish treaty).

No. $14^{24}$ is a case of a license issued under a proclamation permitting the import of timber from enemy countries, under certain guaranties, after the burning of London. No. $15^{25}$ is a case where a pass under the Swedish treaty was disregarded as palpably inaccurate. This opened a wide door. No. $16^{28}$ is a like case, where the master, being examined, contradicted the statements of the pass. (But where there was an apparently valid pass, it was a great departure from the treaty to examine him.)

We find, however, that in case $17,{ }^{27}$ the defect of all bills of lading and charterparties and docquets was held not to prejudice the (Dantzic) ship, so long as she had a valid pass and the lading was on account of the owners. The captors then insisted on the other familiar ground-that the crew were Dutch, they having testified that "their wives and families remain in Omland, which is under the. jurisdiction of the States-General, and contributes to the war." And they admit-another important point-that the king's declaration inviting Hollanders to settle in England with the protection due to English subjects effected no change in their treatment quoad prize law: since, apart from that proclamation, their change of domicile from Holland to England would be enough.

"Nor doth his declaration impart any alteration, because (albeit it be H. M.'s intention and interest to withdraw the Hollanders, by changing their domicile and habitation) neither is, nor was, there any ground of prize because the seaman is or was by nation a Hollander, unless he was an actual residenter there and contributed to the war, which alone ["only"] makes him an enemy."

\footnotetext{
${ }^{24}$ Capt. Wood v. Boyneilson (July I3, I669) I Stair, 636; sub nom. The Raphael, Gosford MS. No. I69, p. 67.

${ }^{25}$ Joachim Burnmaster v. Capt. Dishington (July 29, r67I) I Stair, 745.

${ }^{20}$ Simpson v. Ludke (Jan. 7, 167.3) 2 Stair, 162. (The Fortune.) In this and several other cases, it is assumed that even when the Swedish ship is provided with a pass, the case may be inquired into further, si gravis est suspicio. Whereas, the fact is that such investigation may take place when the pass is not forthcoming. Nobody seems to have troubled to read the Latin text. (Art. ${ }_{5}$ of Treaty of I66r.)

${ }^{27}$ Anderson v. Douglas (Jan. 21, 1673) 2 Stair, 154. (The Sun.)
} 
This distinct recognition of domicile as the sole criterion of enemy character is, I admit, ${ }^{28}$ a clear authority against my own opinion to the contrary. But it must be remarked that it is recognized for prize-law purposes only, and has nothing to do with the position of enemy aliens at common law. The argument for the captors proceeds, relying on the personal or family domicile, and disregarding any such conception as a "trade" domicile (the recent invention of Westlake).

"The employing of such as are in actual enmity, and have not changed their residence, is a partaking with the King's enemies; as wherever such persons are, they will always be as spies, and give intelligence to the King's disadvantage of the condition of his ships, or those of his subjects, in any port where they trade, and while they contribute with Holland, a placade there will soon recall them home to that service, so long as their families are there."

The argument adds that it is the common custom of nations to make prize of any ship when the master is an enemy. And they add, what is inconsistent with their admission of domicile as the criterion of neutrality, that in the Anglo-Swedish treaty, although the Swedes are allowed to use Hollander skippers, yet it is with the express provision "that he change his domicile and become an inhabitant of Sweden." If a change of domicile ipso facto made him a Swede for prize purposes, no such clause would have been required.

The court allowed further proof as to whether Omland was "free" (neutral), or under the jurisdiction of the States-General. But a further point was taken by the captors: that the cargo (corn bound, according to letters found on board, for Amsterdam) was contraband. The answer was that the ship's certificate, disclosing a destination for neutral Ostend (Spanish) was conclusive; that grain is not contraband, unless carried to a city besieged, and that this was expressly recognized by the Treaty of Breda. The captors replied that the treaty was become evacuate and void, by war between England and Holland, the principal parties, and that "accessory parties taking the benefit thereof . . . could not found upon that which was not;" moreover, the king had expressly declared the carrying of corn to Holland to be contraband. To this the claimants answered that the lords ought not to proceed by the king's private instruction, but by his public treaties confirmed by oath, which could not be dissolved by the outbreak of war between two of the parties, contemplating, as they did, the future possibility of wars. Unfortunately we hear no more of this interesting case.

In case $18,{ }^{29}$ the ship's Dantzic pass did not mention the port of destination; and whereas the "tote-brief" said "Bream" (Bremen),

${ }^{\circledR}$ But $c f$. case $\mathrm{I} 3$, supra.

־The Crown (Dantzic) v. Capt. Lyon (Jan. 23, 1673) 2 Stair. 160. 
the master acknowledged it was Amsterdan-a clear case of discrepancy on the primary evidence. Further proof was refused-"the Lords would not admit of contrary probation." Having thus found that ship and goods belonged to the king's enemies, it seems curious that they should "forbear to determine" whether the carriage of victuals to Holland, or the employment of a Holland master, was cause of condemnation. There was no need to determine these points. But the reason is alleged that these points were reserved because the knotty questions raised in The Sun (case I7, supra) were still unsolved, and awaited the royal determination.

Case $19^{30}$ released the neutral" (Lübeck) carrier of enemy goods, but only because the lading was before the war broke out. It is seldom remembered that England at any such recent period acted on the French rule "la robe ennemie confisque le vaissean ami." But at the close of the violent struggle with Holland strange things were done. The point, however, of the legality of such a rule was expressly reserved. The cargo (salt, sugar and tobacco) seems to have been loaded in America, in great part for the Portuguese envoy at Amsterdam (who was a citizen and merchant of that place).

Nos. 20 and $2 \mathrm{I}^{31}$ exhibited a certain discrepancy and concealment of papers: further proof ("contrary positive probation") was allowed the claimants and captors alike. No. $22^{32}$ shows that where, by treaty, a ship's pass, in wartime, was an entire protection if on oath, the defect of such a pass raised a presumption against the claimant. The question was also raised (the ship having been originally Dutch) whether she could acquire a neutral (East Friesland) character pendente bello before touching ${ }^{33}$ at an East Friesland port; and it was determined that she could. This is in accordance with modern English (though not French) practice. The court allowed further proof of ownership (the master having made depositions inconsistent with the pass), but declined to issue a commission to Friesland, as being too near Holland. The witnesses were to come to Scotland, well recommended. "By the common law of nations false documents, or no documents, make prize," and the court was not satisfied with the master's offer to reconcile the discrepancies by his own fresh evidence.

The next case-No. 23 -is an important one in many respects. ${ }^{34}$ The ship and cargo had been condemned on a variance of documents

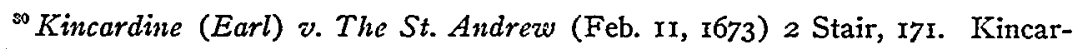
dine had been presented with the prize by the king. He was Admiral-Depute for the Duke of York: see Gosford MS. p. 334 .

${ }^{31}$ The Palm Tree and The Patience v. Capt. Acheson (Feb. 19, 1673) 2 Stair, 173. The White Horse and The Margaret v. Capt. Smeitom (Feb. 21, I673) 2 Stair, I77.

${ }_{32}$ The Prince of E. Friesland v. Capt. Binning (Feb. 21, 1673) 2 Seton, 177, 179.

33 "Touching ground."

s4 The Calmar v. Capt. Smeitonn (Feb. 25, 1673) 2 Stair, 178, 608.
} 
from the master's evidence. The owner, according to the master, was an Englishman, one Sutton, residing at Stockholm, "where he carried on trade with Holland only"; but the master, who had an eighth interest in the ship, was Dutch. The lords found that Sutton was only a blind for Dutch traders, and on the ground that the master and part-owner was Dutch, condemned ship and cargo. On February $6,1678,{ }^{35}$ the claimants returned to the charge, insisting that Sutton, as an English subject residing in Sweden as an English factor, was not to be considered as trading ("participating") with the enemy merely because he put goods on board a ship in which a Dutchman had a share: how could he know where the master lived? The ship was going to England. Observe that the ground of condemnation is not now, as in the earlier cases, that the king's proclamation condemns everything on board a vessel with a Dutch, or partly Dutch, crew ; ${ }^{36}$ but, first, the variance, and then, the "participation" of Sutton with the enemy, involved in putting his goods on board a partly Dutch ship, i. e., it is a case of what is now termed "trading with the enemy." The Dutch character of the master is drawn exclusively from his domicile. He had been duly made a burgess of Calmar, and paid scot and lot there, and traded from there. But his home was in Holland.

"Albeit he was called a master for Sweden in a former war, and had then passes, yet, after the war, he had gone home to Holland, and had his domicile with his mother, in Hem, in Holland, and had resided there the winter before the capture; and though he was called again of new to be a master in the Swedish service, in this war, yet he had not again changed his domicile; which is by ... paying scot and lot, without which none can be burgess in those countries: and which therefore was ordinarily in several places, yet his true domicile could be but in one place, and was found to be in Holland."

As a matter of fact, Sutton turned out to be the king's agent at Stockholm for the purchase of goods, with liberty to import them to England in free or unfree ships: and The Kalmar and The Fortune were the only two that had been stopped. The court released the goods, subject to Sutton's oath verifying such import: otherwise it would seem they would have condemned. And if the Dutch master were simply employed to deceive the Dutch, and to secure the adventure from being taken into Holland, he also should have his interest released to him. ${ }^{37}$

If Sutton (apart from his royal agency) were regarded as a domiciled Swedish trader, it is hard to see why he might not ship his

${ }^{3}$ See, for the intervening proceedings in this case, infra ad fin.

${ }^{23}$ This pretension had been withdrawn.

${ }^{3}$ See, contra, case 22 , supra. 
goods on a Dutch ship without exposing them to condemnation. Either, therefore, his native character was not displaced by his Swedish residence (which may not have amounted to domicile)-or else the principle was by this time adopted of "la robe ennemie confisque le cargaison neutre."38

Case 24 shows the increasing power of the Dutch. It was now the turn of the English to shelter themselves under Swedish colors. As "the King's subjects may, and must, trade under cover of Swedish, or other free [neutral] passes, and otherwise can drive no trade considerable," a discrepancy of papers was held no ground of condemnation. But it was "just ground for bringing up the ship."39 Case 25 is one of post-bellum sale, and almost amounts to a denial of its possibility, since it is laid down that, the sale being in Amsterdam, the proof of it ought to be sworn there, and by reason of the war could not be. ${ }^{40}$

In case 26 , the great question of the confiscability of the ship and her return cargo in cases of contraband was settled in the negative, ${ }^{41}$ but only on the language of the Swedish treaty of 166I, which provides that contraband can in certain cases be seized, but says nothing about its proceeds. The question whether Sweden had the benefit of the Treaty of Breda (England, France, Denmark, Holland) to which she had acceded, but which had been dissolved as between the principals, was raised but not decided.

That the principle "la robe ennemie confisque le vaisseau ami" was at this time accepted seems clear from case No. 27.42 The Treaty of Breda had, in the interest of the Dutch carrying-trade, reversed it, and in the present case it was questioned whether the Hamburgers had adhered to it, and whether it was still valid, quoad hoc. In No. 28, it was held that "joists, balks" and other timber, might be contraband; and that the omission of any port of destination from the ship's papers was fatal to such a cargo. But the question was reserved whether the ship itself was saved by the operation of the Treaty of Breda. ${ }^{43}$

The same state of affairs arose in No. 29 as appear in No. 23. The master, being part-owner, and a domiciled Hollander, infects the whole adventure with a hostile character. The master acknowledged that he was a born Hollander and had left his wife at Amsterdam, and although he had a burgers-ticket in Sweden, this was held insufficient to confer on him the character of a Swede. The vessel had

\footnotetext{
${ }^{3 s} \mathrm{Cf}$. case I9, supra.

${ }^{30}$ The Rostock v. Capt. Brown (Feb. 26, 1673) 2 Stair, 179. The sale was very suspicious, being one from a Dutchman to his Swedish sister.

"See contra, case 22, supra.

"The King David v. Donaldson (Feb. 27, I673) 2 Stair, I80, 220.

"The Patriarch v. Wilson, 2 Stair, 182.

${ }^{43}$ The S. Peter v. Stuart (Feb. 28, 1673) ibid.
} 
a pass, which might have prevented further inquiry by the terms of the Swedish treaty: but it was not duly sealed, and as we have seen, it had become usual to disregard such passes when contradicted by the depositions, however improperly taken. Further proof was refused.

In case 30,44 it is stated that "the throwing of papers overboard is an unquestionable ground of prize." The fact was proved by the supercargo ${ }^{45}$ and the captain's son: but it was said the latter was threatened and the former bribed. In the event, further proof was allowed, and, on July I5, held satisfactory, the cargo being really intended for England, and so insured. The Bonnder ${ }^{48}$ was not so fortunate: spoliation of papers did for her. In this cause, general principles of prize were laid down which justify a little minuteness in examining the case. Once more the pass was contradicted by the master's oath (and the situation of the vessel) - "the skipper's oath being the only mean to secure his majesty against enemies trading under other names" and to evade the treaty. (It will be observed that even in this exigency, the captors did not ask the court to receive evidence dehors the ship.) The curious old custom is referred to, in Gosford's report, of rendering decisions in prize causes within three tides, for the avoidance of delay and damage. And it is expressly determined : $: 7$

(I) That informality in a pass shall not be a ground of condemnation, but only for plea and proof by both sides (as it would be termed in English practice).

(2) That absence of pass, spoliation of papers, or variation in testimony shall, on the contrary, be sufficient to condemn.

(3) Contraband (saving the Treaty of Breda quantum valeret) may be adjudged prize (and the proceeds on the return voyage); things which may be useful for shipping or war are not contraband, but only things "properly and only useful" ad instrumenta bellica. And on July I9, I673, it was expressly added that victual or other (ambiguous) goods carried to Amsterdam are not contraband, according to the Treaty of Breda "which is conformed to the maritime law, making them only contraband when they are carried to a besieged town or castle."

(4) That enemy goods do not infect friends' goods in the same ship (but query, whether enemy ship infects the cargo belonging to friends).-The Mary.

(5) Various circumstances may unite to prove fraud: and if the

"The White Dove v. Alexander (ibid.) I83, 213.

45 "Timberman."

"S (June 12, 1673) 2 Stair, 185, 207 ; Gosford MS.

"See Gosford. 
master is a co-owner and a Hollander, the whole ship and loading is prize "albeit some of the copartners are friends but knew the master to be a Hollander." Duplicity of papers is a ground of condemnation.-The Venus.

In case $32^{48}$ there was a contrariety of documents; but one was a royal pass, which was not needed, and the variance was immaterial, being only that the master's name was interlineated over an erasure. On July I8 captors urged that the cargo was contraband in part, and that new instructions by the king confiscated the ship in such a case, and that Sir R. Wiseman (king's advocate in England) had written to say that pitch was contraband; which was a fait nouveau. Held, that the question could not be reopened.

Case $3^{2}$ was again a question of the Swedish treaty.49 A Swedish vessel was duly provided with a Swedish pass, conforming to the treaty of $x 66 \mathrm{I}$, for a voyage from Nantes to Stockholm with a specified cargo of brandy. She was driven in distress into Portsmouth, unloaded and sold the brandy. She then made a fresh start; went to Nantes and took in more brandy, sailing with the old pass, and an alternative intention of going to Bremen if prevented from reaching her home port. Held, that there was no reasonable ground for adjudication: it would be absurd to have her pass renewed at every port she touched at. The Admiral absolved "without further probation," but further proof was ordered by the Court of Session.

In case $34^{50}$ the master had again admitted that his pass was incorrect and unsupported by oath when granted. It was alleged that the master and part-owner was "by nature" a Hollander, that his being a "residenter" in Copenhagen was falsely stated, and that he was still a Hollander "whereby the ship would become prize, and in consequence the loading." ["Enemy ship, enemy goods."] His residence was sworn by his son and godson to be with his wife in Holland "in a house belonging to himself in property"; and was only two months in Copenhagen four years ago; "and by several other missives taken aboard, written from Holland, she intreats her husband to come home." The claimant replied that an error in the pass does not make it a forged pass. As Prof. Courtney Kenny puts it, a document must misrepresent itself, to be a forgery: that it misrepresents facts is beside the question. A lying document is not necessarily

${ }^{4}$ Winchester v. The St. Andrew (June I3 and July I8, I673) 2 Stair, I87, 216.

${ }^{49}$ Donaldson v. The Debora (June 17,1673 ). The headnote is misleading in saying the point was "What ground of suspicion warrants seizure?" unless it means that something more than the usual grounds of suspicion are requisite in order to interfere with a vessel bearing a Swedish pass-since the treaty bears that no such vessel is to be interfered with, and the only method of evading this was to represent an inaccurate pass as a worthless one.

${ }^{2}$ The S. Katherine v. The S. Mary (June 25, 1673) 2 Stair, IgI. 
a forged document. ${ }^{12}$ "A false pass is that which is forged, having a forged seal or subscription; but albeit some assertions in it be not true, it does not render it false." They urged further that the variance in the pass was occasioned by the misleading formula in the Danish treaty; and that the master had "a chamber" in Copenhagen, and had had his wife there since February, though she had gone back to Holland to see her sister. More cogently, they remark that, if he were really a Dutchman, it could only forfeit his own share. On the other hand, the captors, anxious to disembarrass themselves of the system of passes, insisted that a pass shown to be false in any material particular could be disregarded as a forgery.

They are quite emphatic as to what kind of domicile is meant for prize purposes. It is ordinary civil domicile, and not an artificial trade domicile.

"At one time a party may have many domiciles, but his residence is estimated by his principal domicile, which is always understood when his wife and family are in his own house, unless there were evidences of their separation; for a skipper, who is ordinarily at sea, may have a chamber in many towns where he uses to trade; and though he had a part of his stock [there] and bore contribution for it, yet his chief residence must be where his wife and family were."

They proceed that the wife seems to have taken no furniture or servants to Copenhagen, but only one daughter, whence it seems to be a mere visit. And they contend for the principle that an unfree ship confiscates the loading and that

"a part of the ship being unfree, she cannot be said to be free, and being one body, cannot be condemned in part and [released] in part."

In fact, I do not think there is any English case in which the ownership of a vessel has been split and neutrals allowed to save their share. Cases of goods jointly owned may be adduced: so may cases of pledge and mortgage. But these are another matter.

The court, on the whole, declared the ship [and lading] prize, reversing the Admiral, and treating the pass as a forgery, or at least fraudulent. Fraud, of course, condemned the whole adventure, whether enemy property or neutral.

Case 35 is a clear one of inefficiency and duplicity of documents. ${ }^{52}$ The doctrine of la robe ennemie confisque le vaissean d'ami was distinctly announced by the court, although the shipowners contended that

${ }^{31}$ See Regina v. Ritson (1869) I. R. I C. C. 200 ; Regina v. Kay (1870) 22 L. T. Rep. N. S. 557 (antedated deed), and Regina v. Riley [I896] I Q. B. 309 (antedated betting telegram), both wrongly decided, as it seems to me.

${ }^{22}$ The Vents v. Capt. Wilson (June 26, July I5, I673) 2 Stair, rg6, 2 r2. 
"neuters cannot be hindered, by a war falling in between any princes or states, to continue commerce. . . . If enemies' goods be found on board, these goods may be confiscate; but the neuters, who freely might serve the enemies in any thing but in the war, and so might take their goods in fraught upon their own peril, yet could not thereby confiscate $[i . e .$, subject to confiscation] their ships."

It was answered, à la mode de I9I6, that it was to partake with enemies, either to carry them contraband, or to carry their goods. And although the Treaty of Breda stands contrary, the king has declared it void.

Cases 36,37 , and 38 explain the propriety of condemning without further proof in a clear case.53 The last-named reaffirms the conclusiveness of personal (family) domicile in the enemy country. Case $39^{54}$ shows the mere employment of an enemy master (not being a part-owner) is not enough to condemn. This, it will be recollected, is contrary to former cases ${ }_{5}^{55}$ but the king's instructions had been altered in this particular. Nor is victual contraband, though expressed as such in the Swedish treaty: because at the desire of the Swedish Ambassador, the king, countersigned by Secretary Moriss, had declared that victual and money is contraband only when carried to a besieged place. Nor, if it were contraband, could the ship be captured on the return voyage. (The Lords, however, there being no pass as provided by the treaty, allowed a proof as to Dutch ownership.)

Case 40 is a curiously modern-sounding one. The ship was owned as to three thirty-seconds in Amsterdam. It was argued that this confiscated the whole adventure. Moreover, ${ }^{56}$ the ship was insured in Holland, and so the risk lay upon the king's enemies. ${ }^{57}$ It was replied that, although a partnership by neutrals with enemies after outbreak of war would expose their property to condemnation, there was no obligation, or even opportunity, of dissolving one already subsisting. As to the insurance, it did not change the property and vest it in the insurer, but was only a personal obligation upon him to make up the hazard,

"upon which pretext the King cannot justly confiscate the property of his allies, because they have taken warrandise of his enemies; and that the [neutrals] remain proprietors is clear, that in stress of weather they might throw out the loading."

But the court found that the neutrals should have avoided all con-

\footnotetext{
${ }^{3}$ The Katharine v. The King David (July 9, 1673) 2 Stair, 207. Frazer v. The Flying Hart (July I0, 1673) 2 Stair, 207; Frazer v. The Young Tobias (July ro, 1673) 2 Stair, 208.

${ }^{54}$ Capt. Lyel v. The Leopard (July 16, 1673) 2 Stair, 213.

${ }^{55}$ See Nos. 4 and 7, supra.

${ }^{56}$ The Golden Falcon v. Buchanan (July 17, 1673) 2 Stair, 215.

${ }^{87}$ Cf. The Cap Corso.
} 
nection with the enemy by selling the ship at Amsterdam. The question of insurance, therefore, did not arise.

There was also a further ground of condemnation, in the spoliation of papers: and this was again relied on in case $4 \mathrm{I} ;^{58}$ where also variance of primary evidence, and enemy insurance, were shown. Further proof was allowed, and the ship was proved Swedish, but the loading was left in a singular ambiguity. Sutton of Stockholm deposed that it was shipped on the terms that if it came safe to Britain, it should be his; but if taken by the Dutch, then to be the property of the Swedish Tar Company. The contrariety of pass and oath as to the ship was waived (contrary to what was done in No. 34) because the ship would have been free either way. The spoliation was rejected as resting on a single passenger's evidence. But the ambiguity of the property in the cargo was held fatal to it. It was not as if Sutton had been clearly owner, subject to an insurance by the Tar Company against Dutch capture. It may seem that the variance was not important: both Sutton and the company were friends. But the cargo was tar: and the ambiguity was held evidence of a design that it should go to Holland. By the Swedish treaty, however, the penalty did not extend beyond the cargo.

Case 42 is a strong reaffirmation of the principle that prize domicile is the place where a person has his family, ${ }^{59}$ and not (as Lord Lindley and so many English authorities, making the doctrine of "house of trade" superfluous, will have it) the place where he carries on business. Case 43 was tried on an interlocutory bill, for swifter despatch, the ship having been released by the Admiral. The ship ${ }^{60}$ had been bought in Holland, and taken "before she broke ground in any other dominions"-which was alleged to be, by the custom of nations, a sufficient ground of prize (citing the practice of France and the Spanish Netherlands). It was replied that there was

"neither reason nor custom for such a pretence to hinder neuters to buy ships from enemies more than any other goods, seeing thereby they do not partake of the war, or assist the enemy."

And, although there was no bill of sale, and the alleged Swedish ownership rested solely on the oath of the master, yet his possession was held sufficient, and the vessel was released. The court was again favorable in case $44,{ }^{61}$ where there was a variance of documents. The variance, however (as in No. 24), was necessitated because

"H. M. subjects cannot carry on trade without making use of simulate and colourable documents. . . Otherwise the privateers may watch

\footnotetext{
${ }^{2}$ The Fortune (July 22, I673) 2 Stair, 218.

${ }^{2}$ Capt. Seatom v. The King David (July 23, 1673) a Stair, 219.

${ }^{\infty}$ Cf. No. 22, supra.

"The Live Day (Livadia?) v. Middleton (Nov. I4, I673) 2 Stair, 229.
} 
H. M. ports and seize all his subjects' ships that come in; which never want [are without] such colourable documents, but when they have convoys-which is very seldom."

Further proof was ordered, to be made before the magistrates of Hamburg and Hull.

Case $45^{62}$ turns on a point of practice as to the jurisdiction of the Admiral and the Court of Session respectively. "Admirals being obliged to judge between two tides, by the general custom of nations, could not allow further proof"63 (as to domicile). If the Admiral did, the Court of Session ought to "advocate" the cause into its own hands. A soniewhat curious reply was made, that by the Danish treaty, prize cases were to be judged "by a court of Admiralty" alone; but the Court of Session held that, as judges in the second instance, they were "the King's Great Court of Admiralty," comparing their jurisdiction in consistorial matters, which they could not entertain in the first instance.

Case $46^{64}$ cannot be regarded with much patriotic pride. Dirleton adds a note that he has reported it at too great length-

"à cause que les plus habiles et sçavans des seinteurs opinoyent pour les estrangers, et aucuns de ceux qui estoyent de l'autre coste, estoyent parens ou aliens de Luthquharne, qui estoyt partie; et gagnait par l'arrest 2000 livres sterl. ou environ; et l'emportait par une voix seulement."

The master and part-owner was born in Holland, but had removed with his wife and furniture to Stockholm. A commission was granted to the Stockholm magistrates to take evidence as to the change of domicile by way of further proof, but it was executed ex parte; and the court, though regarding the report as satisfactory, suspended action on it until the other side had taken evidence in its turn. The Stockholm court declined to take any more evidence on the commission, and the Scottish court had then to consider whether their determination that the claimants had pro tanto succeeded in clearing themselves should be made a definitive finding, or whether a new commission should be granted to the captors, or whether the prize should be condemned. The better opinion was that there was so little ground of suspicion, that the primary evidence, corroborated ex parte, was sufficient: or at least that a new commission should be issued. But actually, condemnation passed.

\footnotetext{
¿Stuart $v$. The Seel-fish (Dec. 17, I673) 2 Stair, 281.

"This seems to be the effect of what is meant by "act before answer." The Court of Session instructed the Admiral to alter the procedure by allowing a "contrary positive probation" of change of domicile (if he did not see his way to condemn).

"Capt. Gordon and Ludquharn v. The Winegrape (Dec. I7 and 23, 1676) Dirleton No. 207, p. 93, No. 208, p. 95.
} 
Some jealousy appears between Scotland and England in case $47^{.55}$ A Scottish privateer interfered in the pursuit by Prince Rupert's Nightingale and an allied French galiot of a French ship (Tortoise) made prize by the Dutch. The Scot boarded and took the Tortoise, after ascertaining that the French galiot (which was flying Dutch colors) was really an ally. In the Scottish process by the captor against the owners, the prize commissions for England in Scotland intervened, relying on the Nightingale's capture of the Tortoise's convoy. The privateer replied that no matter who had taken the prize, the Scottish courts have jurisdiction over it, ratione loci, and that, even if not, the English commissioners had submitted to the jurisdiction. The Court of Session allowed these reasons, and sustained the jurisdiction. On the question of substance they decided in favor of the privateer, that the Tortoise would have escaped if the privateer had not cut her off: and that this gave her full title ${ }^{88}$ (subject to the privateer's witnesses being satisfactorily proved to be disinterested). The argument for the privateer is well worked out. Starting from the proposition that the French Tortoise was perfectly vested in the Dutch by capture, it proceeds on the analogy of the Roman law to show that the English and French pursuers had no right in it, but a mere expectation, which it was open to the Scot to defeat. (The difficulties of these inquiries led in the course of time to the simple rule that all ships in sight at the time of capture are entitled to share pro rata.)

There now comes a considerable gap of nearly thirty years before the next case, which is after the Union, in $1705 .{ }^{67}$ It is one of false documents (No. 48). Here the Dutch were allies and the enemy was Spain. Trading with the enemy being improper for an ally, ${ }^{68}$ documents are for a voyage to and from the Canaries. The rather hopeless point was taken that it was right to trade with Spain, because

"Her Majesty is in alliance with King Charles of Spain; and though the Duke of Arigon assumes that title, and has seized and possessed the dominions, that ought not to prejudice private persons in those dominions who have not owned nor recognized him as King Philip."

${ }^{\infty}$ King's Advocate v. Rankin (Feb. I5, I677) 2 Fol. Dec. I77; 2 Stair, 507. Gosford MS. No. 966, p. 640 . The Tortoise. See infra, ad fin.

${ }^{\circ}$ She was within 45 miles of the Dutch coast, and the Nightingale had two other prizes in chase.

"The Katharine v. Capt. Gordon (Feb. 23, 1705) 62 Dalrymple, 78; 2 Fountainhall, 27 ( the better report).

${ }^{{ }_{B}}$ Though the claimants, perhaps more justly, urge that they are amenable only to their own law, which allows them a free trade with Spain. The captors reply that war by necessary consequence imports the shutting up of all commerce; and if any of the confederates, who are sorii belli, should by private treaty agree to trade, such pactions can import nothing in this case. 
But it was answered that on this showing the French ought not to confiscate the goods of Britons-the true subjects of King James VIIT. The Canary documents were found sunk at the bottom of a water-cask, so that the plea that double papers were necessary and usual ${ }^{\text {g9 }}$ was deprived of much of its force. The captors allude to royal letters declaring the opinions of Kings Charles II and James II, and it is interesting to note that they seem to admit that these cannot conclude the court,

"though it be pretended [asserted] that the advising with the King how to decide in cases is against the claim of right, discharging any such letters to be wrote to judicatures,"

yet in these questions of jus publicum, depending on declaration of war, alliances, etc., it was not unreasonable to consult the public authorities.

On May 17, I7I0, ${ }^{70}$ the Joanna of Aberdeen for Virginia was taken by the Pontchertrain which in its turn, with a ransom-bill for 200 guineas on board, and other spoil, was taken with eleven days by Her Majesty's ship Mermaid. It will be seen that the spoil had not been taken infra praesidia, but it had been possessed for twenty-four hours. Had the ownership been divested? Grotius, Zieglius, Voet, Malloy, Lircenius, and the French regulations were cited for and against the twenty-four hour rule. The court found that, both as regards bill and spoil, the original owner remained entitled: this is the modern doctrine. A curious remark is that the ransom-bond would be matter of general average, but not the spoil actually taken on board the cruiser: for this is not sacrificed for the common benefit. And the principle is regarded as clear that recapture of a cruiser with a hostage, instead of a ransombill, on board, discharges the capture. (No. 49.)

After these two cases, we again leap a gulf which extends to г76ז. The limits of the doctrine of continuous voyage are seen very clearly in No. 50. Trade with the French West India Islands-a close tradewas interdicted to neutrals. Doubtless this, "the rule of the war of I756," enabled such a voyage to be stopped, even when the ship which had left the West Indies had already called at a port in Europe. But if she had completed her voyage, and left the goods to be carried on by another ship, condemnation never ensued; no record of condemnation in the case of such a broken voyage exists. And when Sir W. Scott later gave clear expression to the doctrine of stopping the ship after an interposed call-the doctrine of continuous voyagehe never applied it except where the ship was the same throughout. In the present case ${ }^{71}$ the ship was from Trondhjem to Amsterdam,

${ }^{\infty}$ See Nos. 20, 24, 44, supra.

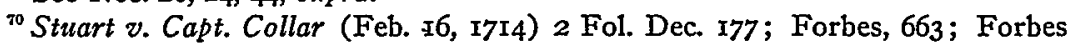
MS. 27.

"The Stavorse Lynbaan v. Capt. Harden (March 3, r76r) 4 Fol. Dec. I44; Fac. Col. No. 27, p. 54 ; 178 Kames, Sel. Dec. No. 178, p. 241. 
both neutral (Danish and Dutch) ports; she had French West India cargo (the property of French subjects) on board. The privateer Boscarven took her into Burntisland. The Judge-Admiral (this is the first time the title occurs) awarded restitution without costs and damages. French property was not confiscable on Dutch ships: AngloDutch treaties, I668, I676; but it was argued that this was not applicable so as to admit the Dutch to carry on a French close trade, which is a different ground of confiscation, and would equally enable. Dutch property coming from those French islands to be condemned: the treaty of 1674 itself extends only to free merces quae in pace subveherentur. And it was attempted to assert that-

"it makes no difference whether a Dutch ship shall bring a cargo directly from the French West Indies to Amsterdam, or if the voyage shall be divided, and the cargo be brought to Trondhjem in order to be there reshipped on board a Dutch vessel. The first and last of these voyages is equally prohibited by the commercial law of France."

But the Court of Session declined to accede to the argument. The voyage to Trondhjem was attackable. But trade between Trondhjem and Amsterdam could not be subjected to constant interference to see if any goods which should never have been at Trondhjem were on board.

It may be suggested that one considerable reason why the "Rule of 1756 " was struck out was this-that the English had (in 1674) conceded to the Dutch liberty to carry enemy goods, without having the foresight to make it a condition that their own goods should be similarly secure vis-à-vis the opponent belligerent. They thus found themselves obliged to respect French goods on board Dutch vessels, while the French were under no corresponding restriction. But for this situation the rather forced doctrine of the impropriety of neutrals engaging in close trade would scarcely have suggested itself.

We have seen that case 49 appears to establish that deductio infra praesidia is necessary to divest the owner's title in captured property. What if someone becomes a bona fide purchaser meanwhile from the captor? Case $5^{\mathrm{I}^{72}}$ was one in which a Newcastle ship, The John \& Robert, was captured by a French privateer and carried into Christiansand, where on Oct. I5, I757, sentence of condemnation passed by decree of the Duke de Penthièvre, High Admiral of France. The Danish judge, however, ordered the vessel to be released as taken within the limits of the port: but his order was reversed by higher tribunals. The vessel was then sold to one Christian Severine Balle, merchant in Christiansand, and sent to Aberdeen under the command of Brink, from whom she was claimed by her former owner. Brink

\footnotetext{
${ }^{72}$ Benton v, Brink (July 23, I76r). The John \& Robert alias The Johama Catharina, 8 Fol. Dec. I43; Fac. Col. No. 49, f. 104.
} 
questioned a Danish edict of May 7, x756, permitting the bringing in and sale of prizes (but the latter only after due condemnation): and the cause was removed from the Aberdeen Bailies to the High Court of Admiralty, and appealed by the Danish purchaser to the Court of Session. It was there pleaded by the original owner that though success in war was effectual to transfer property, yet it was not so with every transitory and casual possession acquired by an enemy. "The law requires a firm possession, and supposes the property to remain with the former owner as long as there is any probable expectation of recovering it." Albericus (Gentilis) and Bynkershoek are added to the authorities cited in No. 49, supra (The Pontchertrain). Groenwegen is referred to on the opposite side, and it is urged that "what is still stronger than a thousand opinions of lawyers or doctors" -general practice - is in favour of the appellant. Certificates were adduced under the seal of Wm. Fuller, procurator-general in England, certifying the condemnation of several vessels in England which had been carried into (neutral) Mediterranean ports. Gentilis is set aside as "not of the number of those distinguished practical writers generally referred to in questions of this kind." And Bynkershoek is explained as laying down no general rule beyond the necessity of firm possession, though observing that deductio in praesidia must always be sufficient. The cases in Malloy are dealt with as referring only to the prizes made by letters of marque: and it is said that these were very distinct from captures made by war-ships or privateers. They were made under license to recoup oneself, and passed under particular rules. ${ }^{73}$ The purchase was founded also on the Danish decree, which their opponents represented as incompetent to decide the question of property. All parties, however, fully recognize that-

"the province of the courts in [a neutral] state is to try whether or no the peace of the port has been violated by the capture. . . . If that has been the case," it is added, "they order [the captor] to restore the possession."

The Court of Session found that what had happened was adequate to pass the property, notwithstanding the ship had never been in France. She had, of course, been out of British reach: and the fact of the Danish decree may have gone for something, being regarded as a decree in rem in the locus rei sitae. ${ }^{74}$

Case $52^{75}$ is one where a recaptured vessel was returned, as having

${ }^{73}$ For this distinction, there are cited Jacob's Law Dictionary, and The Laws of the Admiralty, 219.

${ }^{\pi 4}$ Cf. Imrie v. Castrique (I860, Exch.) 8 C. B. N. S. 405, Castrique v. Imrie (I869) L. R. 4 H. I. 4I4.

"Hunter v. DeBothmer (Count) and Capt. Stewart (July 6, I764). In the Judge-Admiral"s decree, King George is styled "the King of Britain": rather a unique use in an official formula. 4 Fol. Dec. I45; Fac. Col. No. 130, p. 312. 
been taken within neutral limits. The Maria, belonging to a London merchant, Hunter, was bound from Quebec to London with whale-oil, was taken off the Orkneys by the Malice and carried into Norway, where H. M. S. Lynx's boats cut her out. Stewart was dismissed (though afterwards reinstated) at the request of the King of Denmark, yet Hunter called on him to pay over the proceeds, less salvage, and obtained a decree from the Admiral.

Capt. Stewart turned the action into one of multiplepoinding [interpleader], making the Danish Ambassador, the insurers, and the captors parties. The Court of Session decided in favor of handing over the proceeds of sale to the King of Denmark. The House of Lords affirmed the decree.

We get another case of colonial voyage in No. $53 .{ }^{78}$ But it was a direct voyage from San Domingo to the Texel. Condemnation passed in the Admiralty and in the Court of Session, but was reversed by the House of Lords. For in the war of 1778 it was said that the principle laid down for the war of 1756 had been departed from. Probably the comparative weakness of Great Britain was a reason why it was not thought proper to antagonize neutrals.

Case $54^{77}$ shows that the practice was employed in I780 of exempting from capture enemy ships in British ports. ${ }^{78}$ The question was as to whether a Dutch ship proceeding to Leith in pursuance of a charterparty and arriving there in ignorance of the war, was within the terms of the proclamation of exemption. It will be seen that no objection was raised to the suit on account of the hostile quality of the claimants (William t'Hart, master, and Class Iaanen Zoonen, owner). This is in accordance with the opinion expressed in the Lee-Murray Report of $1757^{70}$ to the same effect, that enemies have a locus standi in prize causes. The court, in fact, struck by the hardship of the case, did restore the Noord Holland to her owners. What the latter did with her unfortunately we do not know. Not improbably she was sold, and the proceeds taken circuitously to Holland. Or she may have returned under a safe-conduct.

In June, I797, the Diana, merchantman, casually recaptured the Lady Bruce. The owners promptly insured their anticipated salvage. The prize being again retaken by a Dutchman, they sued on the policy. It was replied that they had no insurable interest, being non-commissioned. So Lord Armsdale thought: but the Court of Session observed that although the recapture by the Diana might not have been effective

${ }^{78}$ Volkert Hendricks v. Wm. Cunningham (Jan. 30, 1781) 4 Fol. Dec. I45; Fac. Col. No. 85, p. 14I. The Catharina. The case is notable as having been decided by Lord Braxfield as Lord Ordinary ("Weir of Hermiston"). Cf. No. 50, sicpra.

"The Noord Holland v. The King Alfred (Dec. I4, I78I) Fac. Col. No. 3, p. 7.

${ }^{78}$ Orders in Council 20, Dec. 22, 1780, Feb. 16, 1781.

${ }^{\pi} \mathrm{Cf}$. my edition, p. I34. 
in a competition with the king or his officers, the insurers were not entitled to state any such plea; and the insurance ought to be made effectual. Clearly, nobody thought at that date that acts of war by a private ship were to be considered as acts of piracy! Not even revolutionary France appears to have entertained the notion.

We may pass rapidly over the more recent cases collected in the appendix. In case $I, 30$ the modern doctrine is laid down that it is neither twenty-four hours' possession nor deductio infra praesidia that divests the property in prize, but sentence of condemnation passed in an enemy territory or territory ${ }^{81}$ under enemy control. It is said in argument that there is no instance of an enemy appearing in prize process. The investigation of the cases must have been very superficial, to allow of such a statement. 82

A most interesting-and I think still an undecided-point arises in case II. Can a neutral trade direct between opposing belligerents? If he is domiciled in either country, of course such trade is trading with the enemy. And clearances for enemy ports can, I suppose, be refused by municipal law. But on the high seas, can a neutral's ship or goods be confiscated for such trading, if, viis et modis, they have got a clearance? The Stettin, ${ }^{83}$ in April, I799, sailed from Rotterdam for Leith, and was taken by the revenue cuitter Coburg. The ship was given up to the owners, and Cordes and Gronemeyer of Hamburg claimed the cargo. It was held that the traffic was legitimate, so long as it was not a blind for a specific enemy export. The possession of the bills of lading by the neutral was considered strong evidence of the genuineness of his ownership and enabled the majority to decide for the claimants: though it was urged

"it must not be a trade where the British merchant commissions the goods from the Dutch merchant, and the neutral merely acted as agent, in order if possible to deceive the two countries, and forward this unlawful intercourse."

The fact that the neutral-agent or not-was made entire master of the property, was held sufficient to rebut any suspicion of Dutch (or Scottish) ownership.

In the writer's view ${ }^{84}$ the reason of the prohibition of trade not being primarily to injure the enemy (for the injury is mutual), but

${ }^{80}$ Roman numerals assigned to cases are our own.

a This extension was only carried by a majority. Several judges thought Holland an independent state, and that, though it was allied to France, no French court could be established there. Others thought it a mere province of France.

Wake v. Banerman (July 7, I801). The Stettin alias The Mary. Fac. Col. No. 246 , p. 556 .

${ }^{80} \mathrm{O}^{\prime N e a l}$ v. Cordes and Gronemeyer (Nov. I9, 1805) Fac. Col. No. 221, p. 498, No. 2, p. 7 .

see War and its Legal Results. 
the dangers of direct communication, trade conducted by a neutral is legitimate enough in principle.

From M. P. Brown's Supplement to the Dictionary of Decisions in the Court of Session (1826) may be extracted notes of a few other cases. No. III (Vol. II, p. I68) in a case of July 24, I673 (The Pearl) is one of variance of evidence..$^{85}$ No. IV (p. I74) ${ }^{86}$ reports a further point which arose in the Calmar. A small quantity of brass wire was shipped along with the tar, and claimed for Sir Francis Clark, of London. But there was no document relating to it on board. However, it was laid down very strongly that the absence or duplicity of documents, which might be fatal to a "neuter," was not to be relied on to the prejudice of the king's subjects resident in his dominions. Nor could a latent enemy interest in the vessel prejudice them. The important point was added, that if the wire was sold after adjudication, the captor would only be liable to restore the price obtained: otherwise he must pay the cost of the wire at"Stockholm ("such wire not having a known price here"). No. V (p. I83) ${ }^{87}$ is a case like No. 9, supra. Sir James Stamfield and his partners had paid over the tenth and fifteenth shares of the proceeds of their privateer's capture. On appeal, the ship was restored, the Crown disgorged the fifteenth, and now Sir James sued the Admiral for the tenth. This, it was replied, was "sentence-silver," due for the Admiral's trouble: but, since the obvious answer was that his trouble was the same even when he did not condemn at all, he was obliged to restore the tenth. Case VI (Vol. III, p. 23) ${ }^{88}$ is one of recapture and postliminium, and only the argument is given. Case VII (p. I25) ${ }^{80}$ is another report of the Tortoise (supra). It is curious for the citation of Plutarch, Quaest. Greganica, 29, who observes that the Isle of Acanthus being deserted, it was adjudged to the Chalcidians who first entered it, and not to the Andrians, who first took symbolical possession by throwing in a dart: an early instance of effective occupation! Vinnius, ad (?E) dictum If I3, Alexander King's Tractatus consuetudinum navalium (tit. 4), Aerodius, Pandectae rerum judicetarum (tit. de acq. rer. dom., c. Io), and Voet, De Jure Militari were also cited.

And the curious remark is added, of date Feb. I6, I677:

"The Lords [of Session] preferred the Scots privateer to the King, to give a demonstration of their equity that they durst determine against the King. This was done, valde reclamante Praeside, for Sir James Stamfield's sake."

\footnotetext{
${ }^{85} 2$ Stair, 220.

${ }^{8 s}$ Clark v. Smeitom (Dec. I3, I673) 2 Stair, 220. Cf. The Calmar, supra.

${ }^{8}$ Stamfield v. Lennox (Duke) (Jan. 29, 1675) 2 Stair, 313.

snon. (July, I673), Fountainhall, Advocate's MS. No. 4I8, p. 224.

The Tortoise. Fountainhall, et supra, No. 535, p. 273.
} 
This, in the days of Blindy Mackenzie, when we are accustomed to think of the Scottish Bench as the king's tool!

Case VIII is an afterglow of the Calmar. Fountainhall explains that in December, I676, the king "with Sir Lionell (Leoline) Jenkins, one of the Judges of the Admiralty of England, wrote to the Lords of Session remonstrating with them for having declared" the ship and loading prize, mereiy because some of the crew were Hollanders. ${ }^{90}$ "This was charged upon John Inglis, and he was blamed for informing the Swedes resident and the Stockholm College of Commerce." The lords wrote up a vindication of themselves, and of the Scots' practice of not making public the depositions in preparatorio, though they admitted that such secrecy was elsewhere characteristic of courts of equity, and not of law. But the king in April, 1677, peremptorily called for the depositions, and for the parties to attend him at Whitehall. John Enterkin "the king's writer" lodged an "unheard of" summons to that effect, "which is a most extraordinary act, and astonished all: for, besides that it may be used as an argument of our dependence on England," it would be a precedent for a general practice of appeal to the king in person: "so it is a sore wipe upon the Lords . . . and called twenty times worse than Almond's appeal from them to Parliament in February. I674." Fortunately, His Majesty, "being better informed" wrote a new letter.in June confirming the finality of the decisions of the Lords of Session. "It is hard," says Fountainhall, "to make a King contradict himself in a month's time." But there was no sinful pride about Charles II.

Thereupon, on July 27, the lords found the ship prize. "And the President tartly reproved John Inglis for blowing up the poor strangers and making them believe the Lords had done them injury and injustice," and did not understand the law of nations. On July $3 \mathrm{I}$, however, John Inglis, sticking to his guns, obtained a new hearing, and the lords then released the ship, as freighted for $H$. M. service. "And on this knock, in a trice, did the Lords retract four consecutive sentences of their own, finding it prize. . . Some thought Lauderdele influenced this change." On February 7,1678 , they went into the matter again: "and, because of John Inglis, advocate, his passion in the matter, anagrammatized the clamour," but finally declared the ship free, subject to the master's oath that it was not Dutch property.

John Inglis appears to have been a worthy ancestor of his namesake, of Glencorse, in pertinacity and independence.

\footnotetext{
${ }^{\infty}$ This is not a fair observation: it was not the old allegation of Dutchmen being among the crew that was founded on, but the use of a part-owned enemy ship by a British subject.
} 